\title{
Extinction Probabilities in a Remnant Population of Ovis canadensis mexicana ${ }^{1}$
}

\author{
Tom WATTS \& Walt CONLEY
}

\begin{abstract}
Watts T. \& Conley W., 1981: Extinction probabilities in a remnant population of Ovis canadensis mexicana. Acta theriol., 26, 26: 393-405 [With 3 Tables \& 1 Fig.].

Exploitation by man of bighorn sheep, Ovis canadensis, Shaw, 1804, in North America has resulted in numerous remnant populations, existing in isolation from other sheep. The continued survival of these populations is dependent on the biological potential of the remaining animals and on management programs initiated by man. One such remnant herd of bighorn sheep O. c. mexicana (Merriam, 1901), inhabiting the Big Hatchet Mountains, Hidalgo County, New Mexico, experienced a $50 \%$ decline (from 22 to 13 ) in the adult component between 1976 and 1978. Computer simulations were conducted to address the questions: "what are the probabilities of survival or extinction for the 1978 population?" and "what effects did the 1976 to 1978 reduction have on these probabilities?" The extinction rate for the 1978 population was $12 \%$. The observed decline increased the exinction rate from 0 to $12 \%$, and decreased the potential population size after 18 years by $42 \%$. A hypothetical $50 \%$ reduction of the 1978 adult segment, increased the extinction rate to $20 \%$ and further reduced the population potential by $32 \%$. Conversely, the simulated addition of 10 ewes and 5 rams, between three and five years of age, reduced the extinction rate to zero, and increased population potential by $211 \%$. The 1978 population has a definite chance of going extinct, and the trend since 1976 indicates that it could occur sooner than expected. From a demographic standpoint, introduction of 15 relatively young sheep could initiate a significant upward trend in population growth

[Dept. Fishery and Wildlife Sci., New Mexico State Univ., Las Cruces, New Mexico 88 003, U.S.A.].
\end{abstract}

\section{INTRODUCTION}

Bighorn sheep, Ovis canadensis, in North America are restricted to precipitous terrain; O. c. canadensis to the slopes of northcentral and northwest mountain chains, and the several desert subspecies to arid mountain ranges in the southwest (Buechner, 1960). Historically, sheep populations were loosely connected by strips of habitat along mountain ranges and narrow movement corridors between ranges (Geist, 1971). After European man arrived, many sheep populations were exploited to extinction, thus interrupting movements between adjacent populations.

1 Journal article 737, Agricultural Experiment Station, New Mexico State University, Las Cruces, New Mexico 88003 , U.S.A. Address reprint requests to W. Conley. 
As a result, many herds now exist in complete isolation from other sheep (Bear \& Jones, 1973; Monson, 1971). The continued survival of such populations is dependent primarily on the biological potential of the existing animals, ingress being zero, and on management programs initiated by man.

A remnant population of $O$. c. mexicana inhabits the Big Hatchet Mountains of southwest New Mexico. This herd declined from an estimated 125 to 150 animals in the 1950's (Gordon, 1956) to approximately 22 in 1976 (Lenarz, 1979). In 1978 the population consisted of 10 adults and 3 lambs, the lowest estimate yet recorded for the Big Hatchets (Watts, 1978). In this paper we address the questions: "what are the probabilities for continued survival or extinction of the Big Hatchet sheep?", "what effect did the 1976 to 1978 reduction have on the probabilities?", and "how would these probabilities be affected by further reduction or supplemental introduction?"

\section{SURVIVAL AND FERTILITY SCHEDULES}

Survivorship data for bighorn sheep are available from Woodgerd (1964), Hansen (1967) and Geist (1971). Hansen's (1967) data, comprised of 374 ewe and ram skulls, provide the most extensive base for survivorship determination. These skulls were aged by counting horn annuli

Table 1

Life table generated from data provided in Hansen (1967) following Lenarz \& Conley (1980).

\begin{tabular}{rccccc}
\hline$x$ & $l_{x}$ & ${ }_{x}{ }^{*}$ & $p_{x}$ & $m_{x}$ & $B_{x}$ \\
\hline 0 & 1.000 & 1.000 & 0.500 & 0.000 & 0.000 \\
1 & 0.500 & 0.500 & 0.750 & 0.000 & 0.000 \\
2 & 0.214 & 0.375 & 0.989 & 0.000 & 0.000 \\
3 & 0.212 & 0.371 & 0.987 & 0.500 & 0.800 \\
4 & 0.209 & 0.366 & 0.989 & 0.500 & 0.800 \\
5 & 0.207 & 0.362 & 0.964 & 0.500 & 0.800 \\
6 & 0.199 & 0.349 & 0.945 & 0.500 & 0.800 \\
7 & 0.189 & 0.330 & 0.900 & 0.500 & 0.800 \\
8 & 0.169 & 0.297 & 0.905 & 0.500 & 0.800 \\
9 & 0.153 & 0.269 & 0.862 & 0.500 & 0.800 \\
10 & 0.132 & 0.232 & 0.805 & 0.500 & 0.800 \\
11 & 0.107 & 0.187 & 0.591 & 0.500 & 0.800 \\
12 & 0.063 & 0.110 & 0.518 & 0.500 & 0.800 \\
13 & 0.032 & 0.057 & 0.368 & 0.500 & 0.800 \\
14 & 0.012 & 0.021 & 0.286 & 0.500 & 0.800 \\
15 & 0.003 & 0.006 & 0.334 & 0.500 & 0.800 \\
16 & 0.001 & 0.002 & 0.000 & 0.500 & 0.800 \\
\hline
\end{tabular}

* Survival values after yearing survival increased. 
(Hansen, 1976), which provides accurate ages for rams but only minimum ages for ewes (Geist, 1966). The skulls in each individual age class were summed to provide $D x$ values (the number of individuals dying during age $x$ to $x+1$ ). Hansen's (1967) data were summarized by Lenarz \& Conley (1980) and are presented in Table 1. The survival values presented in Table 1 are defined as:

with

$$
l_{x}=\frac{n_{x}}{n_{0}}
$$

$$
n_{x}=\sum_{i=x}^{i=w} D_{i}
$$

where $n_{x}$ represents the number of individuals in the $x$ th age class; $w$ being the last age class. Survival values, $l_{x}$, are defined as the probability that an age zero individual will survive to enter the $x$ th age class. The $l_{x}$ column contains values calculated from the original data (Hansen, 1967) and the $l_{x}{ }^{*}$ column contains survivorship values calculated after yearling survival was adjusted upwards to provide a positive rate of population increase (Lenarz \& Conley, 1980). Hansen's (1967) data were generated using combined sex-skulls, which assumes identical survival patterns for males and females. Although some undisturbed desert sheep populations exhibit higher proportions of rams (Welles \& Welles, 1961; Sudgen, 1961; Monson, 1963), there is no data on dissimilar survivorship for rams and ewes. Due to rapid decomposition of lamb and yearling skulls, $l_{x}$ values for these age classes were determined from annual water hole counts (Hansen, 1967).

Fertility, $m_{x}$, is defined as the average number of female offspring produced by an $x$ to $x+1$ female, who is producing (Conley, 1978). Fecundity of bighorn sheep is one lamp per reproductive period (Geist, 1971). Twinning does occur (Spalding, 1966) but with such low frequency that its contribution to population growth is negligible. A sex ratio of one $(\mathrm{M} / \mathrm{F})$ at birth is assumed.

Initial age of reproduction for ewes was set at three years. Captive and high quality ewes may breed at two years (Deming, 1955; Woodgerd, 1964), and in one instance, 10 to 11 months of age (McCutchen, 1977). However, in most wild populations lambing does not occur until the third year (Geist, 1971).

Percent breeding, $B_{x}$, represents the proportion of ewes, three years or older, producing lambs in a given year t. Hansen (1967) reported a value of 70 lambs per 100 ewes, however, classification of yearling 
rams as adult ewes could bias estimates downward (Geist, 1971; Hansen, 1967). Population simulations using an optimum age and sex composition (see Lenarz and Conley, 1980) and a $B_{x}$ of 0.80 resulted in a finite rate of increase, $\lambda$, of 1.023 . Since this defines a moderately increasing population, $B_{x}=0.80$ was used as the maximum percent breeding attainable.

\section{POPULATION SIMULATIONS}

Population simulations were conducted using a FORTRAN IV version of a modified Lotka (1956) model as discussed by Conley (1978). Population size $N$, at time $t$, was determined from:

$$
N_{t}=\sum_{x=0}^{w} n_{x, t}
$$

Age specific survival values were calculated from:

$$
P_{x}=\frac{1-l_{x}-l_{x+1}}{l_{x}}
$$

The number of female young entering the population at time $t$ is obtained from:

$$
N_{0, t}=\sum_{x=0}^{\infty} N_{x, t} M_{x} B_{x}
$$

which describes a population composed entirely of females. To simulate a two-sex population we define the number of lambs as:

plus

$$
N_{0, t, 1}=\sum_{x=}^{\infty} N_{x, t, 1} M_{x} B_{x}
$$

$$
N_{0, t, 2}=\sum_{x=0}^{\infty} N_{x, t, 1} M_{x} B_{x}
$$

Where $1=$ females and $2=$ males (assuming a sex ratio of one at birth). Total population size $\left(N_{t}\right)$ is then obtained from:

$$
N_{t}=\sum_{x=0}^{\infty} N_{x, t, 1}+\sum_{x=0}^{\infty} N_{x, t, z}
$$

A characteristic of the Lotka, model is that the population is projected into time $t+1$ from $t=0$ before reproducing. To compensate, the ap- 
propriate number of lambs were placed in the $x=0$ age class of all initial populations.

Two types of survivorship were used. The deterministic $p_{x}$ function computes survival into the subsequent age class for the entire $n_{x}$, allowing proportions of individuals to survive. The stochastic from draws a random number $(0.0 \leqslant r \leqslant 1.0)$ for each individual: if this number is less than or equal to $p_{x}$, the individual survives into the $x+1$ age class. For large populations the stochastic model will closely approximate the deterministic model. In small populations, where the survival or mortality of single individuals is significant, the two may differ widely.

\section{POPULATION STRUCTURES}

The 1976 population structure of the Big Hatchet sheep was determined by Lenarz (1979). Rams ages were estimated from horn size and relative dominance status. Ages of adult ewes were not determined. These animals were placed in minimum age classes (three to six years) to allow for maximum reproductive potential (Fisher, 1958). The 1978 population structure was determined by Watts (1978) in the same manner. The age structures are shown in Table 2.

\section{BREEDING SCHEDULES}

The reported number of lambs born per 100 ewes in wild bighorn populations varies from 13 to 100 (Streeter, 1970). To simulate these fluctuations in percent breeding, 18-year simulations were conducted using various good year-bad year schedules. The occurrence of bad years is based on relationships among precipitation, vegetation emergence and nutritional level of forage for bighorn sheep. Although no quantified correlation is known, a sequence of events can by hypothesized. Beatly (1974) has shown that a minimum of $2.54 \mathrm{~cm}$ of precipitation in either September, October or November is necessary for vegetation emergence and growth the following spring (Mojave Desert). The probability of this minimum rainfall not occurring in a given year in the Chihuahuan Desert is 0.3023 (Conley, Nichols \& Tipton, 1978). Therefore, in approximately one out of three years there will be reduced vegetation emergence, resulting in a reduction of forage quality and quantity available to the sheep in the Big Hatchets. Domestic ewes maintained on low quality forage exhibit reduced ovulation rates (Clark, 1934) and reduced lambing rates (Marshall \& Potts, 1921; Miller, Hart \& Cole, 1942; Wallace, 1948) which translate into reduced percent breeding (as defined earlier). Consequently, we defined a bad year as a reduced $B_{x}$ value, arbitrarily set at $0.50,0.60$, or 0.70 . Since the probability of a 
bad year is one in three, six of the 18 years per simulation were assigned reduced $B_{x}$ values. Three patterns of bad year frequency were used.

with

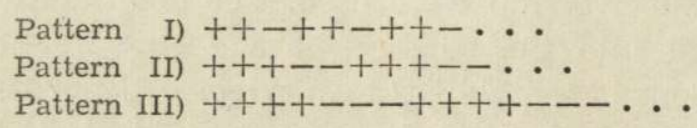

$+=$ Good Year; $-=$ Bad Year.

The sequences of $B_{x}$ values $(0.50,0.60,0.70)$ used in each pattern were generated from a random number table. Three schedules were generated for each of the above patterns. After conducting exploratory simulations, one schedule for each pattern was randomly chosen for more extensive simulations. The differences among schedules within each pattern were negligible.

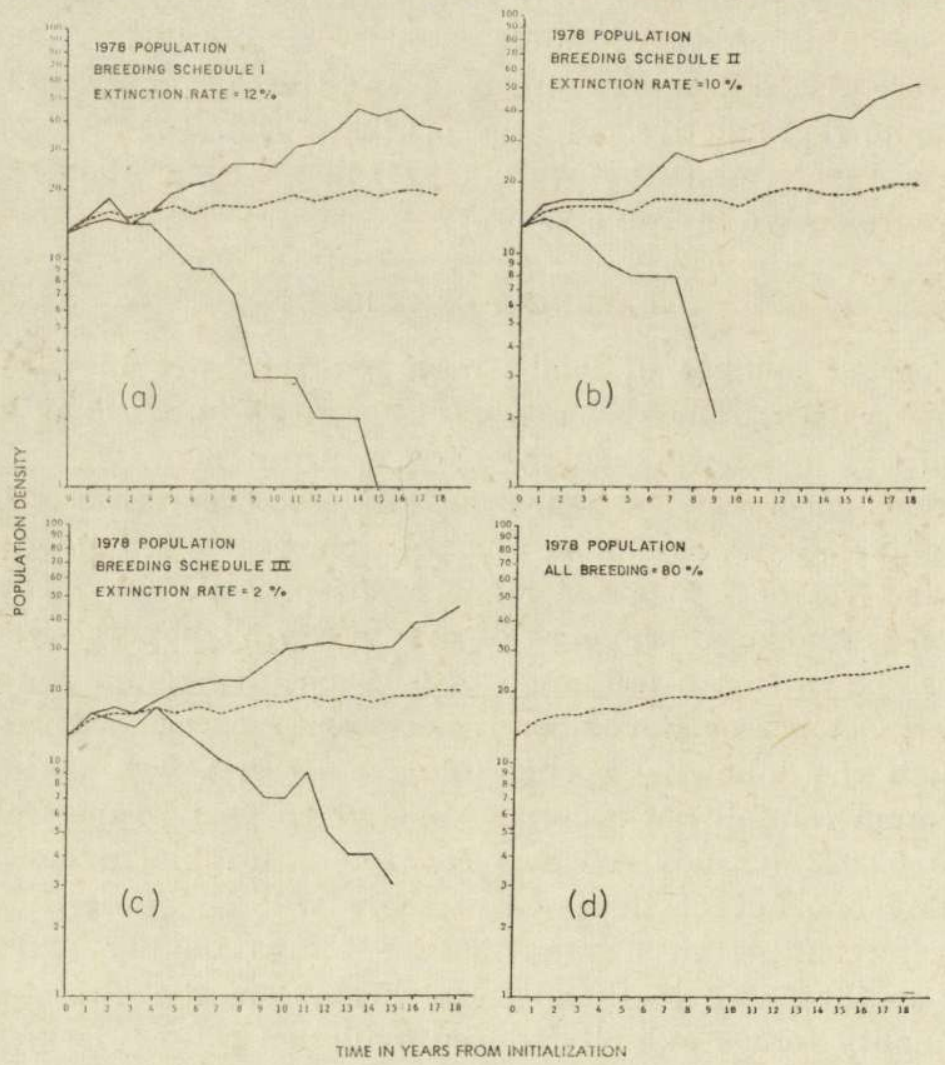

Fig. 1(a) Simulations of the 1978 population using bad year pattern I, see text for discussion of patterns. (b) Simulations of the 1978 population using bad year pattern II. (c) Simulations of the 1978 population using bad year pattern III. (d) Simulation of the 1978 population using all good years. 


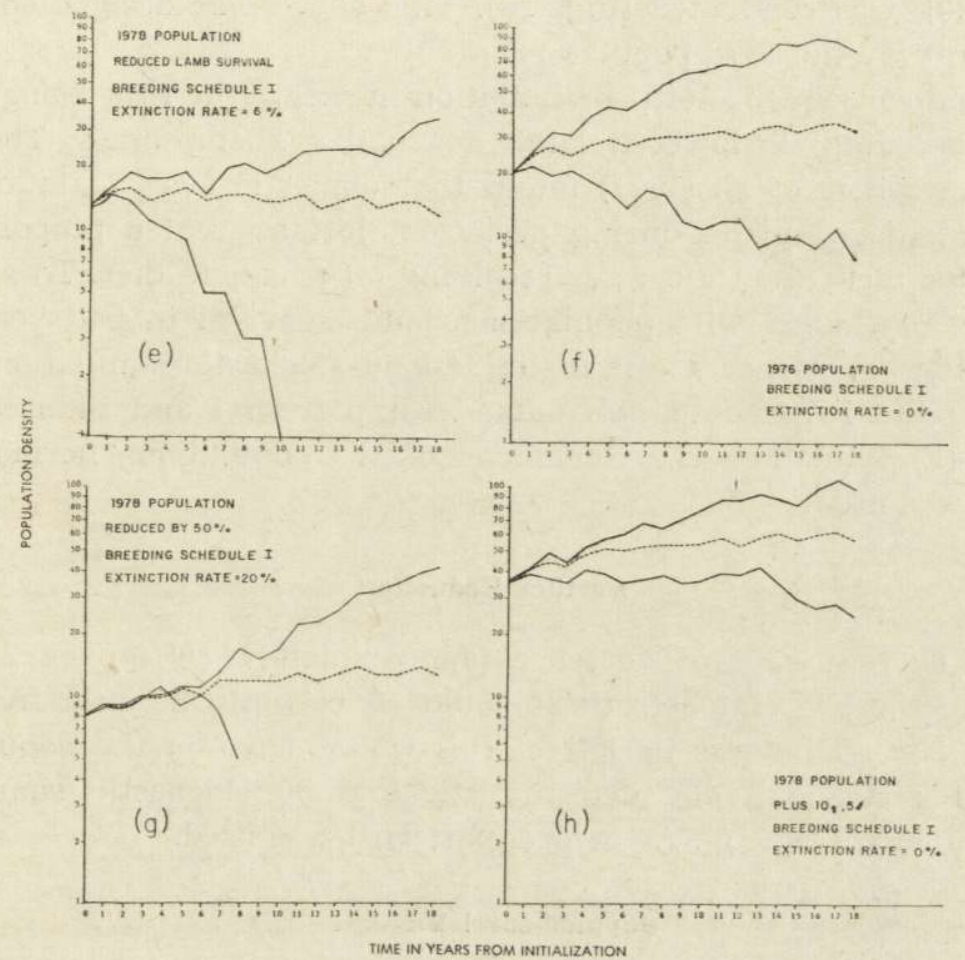

Fig. 1(e) Simulations of the 1978 population using bad year pattern I with reduced lamb survival. (f) Simulations of the 1978 population using bad year pattern I. (g) Simulations of the reduced 1978 population using bad year pattern I. (h) Simulations of the increased 1978 population using bad year pattern I.

\section{RESULTS}

Extinction occurred when the number of individuals of either sex fell below one. To determine extinction rate, one deterministic and 50 stochastic simulations were conducted for each of the three bad year patterns (Figs. 1a, 1b, 1c). In these figures the solid lines represent the maximum and minimum simulations and the dashed line the deterministic simulation.

The probabilities of one, two or three bad years in a row are 0.3023 , 0.0913 , and 0.0276 , respectively. Statistically, pattern I is the most probable and intuitively we would expect it to more closely approximate the actual situation. On this basis, pattern I was chosen for the remaining simulations.

To assess the effect of bad year schedules on population growth, a deterministic simulation of the 1978 population, using all good years, 
$\left(B_{x}=0.80\right)$, was conducted (Fig. $\left.1 \mathrm{~d}\right)$. This curve was designated as the upper limit for the 1978 population.

A second consequence of poor nutrition in sheep (the first being reduce percent breeding) is lowered lamb survival. Thompson \& Thompson (1948) and Miller et al. (1942) found that domestic ewes maintained on a low nutritional plane during gestation, lost a greater proportion of lambs after birth than did ewes receiving an adequate diet. To simulate the effect of this in wild populations, lamb survival in bad years was reduced by $50 \%$. One deterministic and 50 stochastic simulations were run using the 1978 population data, with pattern I and reduced lamb survival (Fig. 1e). For the remainder of the simulations normal lamb survival was used.

\section{Further Reduction}

If the current rate of decrease (approximately $50 \%$ over 2 years) persists in the Big Hatchets there could conceivably be only five adult sheep by 1980 . To assess the effect this would have on the population's chances for survival, one deterministic and 50 stochastic simulations were conducted (Fig. 1g). As before, pattern I was used.

\section{Supplemental Increase}

It might be advantageous to introduce additional sheep into a remnant population. To determine the effect of such an introduction, one deter-

Table 2

Population structures used in simulations. See text for discussion.

\begin{tabular}{|c|c|c|c|c|c|c|}
\hline \multirow[b]{2}{*}{$x$} & 1978 & 1976 & \multicolumn{2}{|c|}{1978 - Reduced } & \multicolumn{2}{|c|}{1976 - Increased } \\
\hline & F M & F $M$ & F & M & $\mathrm{F}$ & M \\
\hline 0 & 21 & 22 & 2 & 1 & 7 & 5 \\
\hline 1 & 00 & $\begin{array}{ll}0 & 1\end{array}$ & 0 & 0 & 0 & 0 \\
\hline 2 & 00 & 20 & 1 & 0 & 0 & 0 \\
\hline 3 & 1 & 20 & 1 & 0 & 4 & 3 \\
\hline 4 & 2 & 20 & 1 & 1 & 5 & 2 \\
\hline 5 & 2 & 21 & 1 & 0 & 6 & 1 \\
\hline 6 & 0 & 12 & 0 & 0 & 0 & 0 \\
\hline 7 & 0 & $\begin{array}{ll}0 & 1\end{array}$ & 0 & 1 & 0 & 1 \\
\hline 8 & 0 & 1 & 0 & 0 & 0 & 2 \\
\hline 9 & 0 & 2 & 0 & 0 & 0 & 1 \\
\hline 10 & 0 & 0 & 0 & 0 & 0 & 0 \\
\hline 11 & 0 & 0 & 0 & 0 & 0 & 0 \\
\hline 12 & 0 & 0 & 0 & 0 & 0 & 0 \\
\hline 13 & 0 & $\begin{array}{ll}0 & 0\end{array}$ & 0 & 0 & 0 & 0 \\
\hline 14 & 0 & 0 & 0 & 0 & 0 & 0 \\
\hline 15 & $\begin{array}{ll}0 & 0\end{array}$ & $\begin{array}{ll}0 & 0\end{array}$ & 0 & 0 & 0 & 0 \\
\hline Total & 76 & 1110 & 5 & 3 & 22 & 15 \\
\hline Adults & 10 & 17 & & & & \\
\hline Lambs & 3 & 4 & & & & \\
\hline
\end{tabular}


ministic and 50 stochastic simulations were conducted using a hypothesized population structure, with pattern I. This population consisted of the 1978 herd, plus 10 ewes and five rams, all between three and five years of age (Table 2). The appropriate number of lambs were added to simulate pregnant ewes.

\section{DISCUSSION}

Examination of Figs $1 \mathrm{a}, 1 \mathrm{~b}$, and $1 \mathrm{c}$ indicates that pattern I produced the lowest deterministic total $\left(\mathrm{N}_{18}=19\right.$, i.e., total population size at $\left.t=18\right)$ and the high extinction rate $(12 \%)$ (Table 3$)$. Apparently, the longer sequence of good years in patterns II and III compensated for the less frequent, yet longer sequence, of bad years. In pattern I the increased frequency of bad years acted to slightly depress population growth. However, the differences among the $\mathrm{N}_{18}$ deterministic population sizes for the three patterns were small $\left(0--5^{\%} \%\right)$.

Table 3

Summary results of population simulations.

\begin{tabular}{|c|c|c|c|c|}
\hline $\begin{array}{l}\text { Population } \\
\text { Structure }\end{array}$ & $\begin{array}{l}\text { Deterministic } \\
\text { Pop. Size }\end{array}$ & $\begin{array}{l}\text { No. of } \\
\text { Stoch. } \\
\text { Runs }\end{array}$ & $\begin{array}{l}\text { Stochastic } \\
\text { Range }\end{array}$ & $\begin{array}{l}\text { Extinc- } \\
\text { tion } \\
\text { Rate }\end{array}$ \\
\hline $\begin{array}{ll}1978 & I^{*} \\
1978 & \text { II } \\
1978 & \text { III }\end{array}$ & $\begin{array}{l}19 \\
20 \\
20\end{array}$ & $\begin{array}{l}50 \\
50 \\
50\end{array}$ & $\begin{array}{l}\text { Extinct } t=15 \text { to } 37 \\
\text { Extinct } t=9 \text { to } 53 \\
\text { Extinct } t=15 \text { to } 47\end{array}$ & $\begin{array}{r}12 \% \\
10 \% \\
2 \%\end{array}$ \\
\hline $\begin{array}{l}1978 \text { I with reduced } \\
1976 \text { I } \\
1978 \text { I Reduced } \\
1978 \text { I Increased }\end{array}$ & $P x$ & $\begin{array}{l}50 \\
50 \\
50 \\
50\end{array}$ & $\begin{array}{l}\text { Extinct } t=10 \text { to } 35 \\
8 \text { to } 80 \\
\text { Extinct } t=8 \text { to } 42 \\
25 \text { to } 103\end{array}$ & $\begin{array}{r}6 \% \\
0 \% \\
20 \% \\
0 \%\end{array}$ \\
\hline
\end{tabular}
discussion.

The curve in Fig. 1d represents the upper limit of population growth for the 1978 population. The difference between the deterministic population totals for pattern I (Fig. 1a) and the upper limit represents a $27 \%$ reduction in the potential number of sheep at $t=18$ (Table 3 ), attributable to the bad year schedule. In assessing the effects of lowered lamb survival (Fig. 1c) we found that the extinction rate for this series $(6 \%)$ was only half as great as the rate for simulations made using normal lamb survival (Table 3). However, the reduction in deterministic population size at $t=18$, was $37 \%$. If an infinite number of stochastic simulations were conducted, we would expect the series with higher lamb mortality to go extinct in $37 \%$ more cases. The 18 year deterActa theriol., 9 
ministic simulation resulted in a net loss of one individual, indicating a slowly declining population.

The simulations in Fig. $1 \mathrm{f}$ illustrate a range of possible growth patterns for the sheep population as it existed in 1976. Comparing these results with those shown in Fig. 1g allows us to determine the effects of the population decline observed between 1976 and 1978 .

The extinction rate for the 1976 population was zero (Table 3). The difference between the 1976 and 1978 deterministic population sizes was $42 \%$. In effect, the population reduction has decreased the population potential (at $t=18$ ) by $42 \%$, and has increased the probability of extinction of approximately $12 \%$.

Considering the downward trend in the Big Hatchet sheep population between 1976 and 1978, a further decline is probable. The effects of a hypothetical $56 \%$ reduction presented in Fig. $1 \mathrm{~g}$. The hypothetical population contained five adults and three lambs (Table 2). Three lambs $\left(B_{x}=1.00\right)$ instead of two $\left(B_{x}=0.66\right)$ were placed in the initial population to generate maximum potential estimates. The deterministic population size at $t=18$ of 13 sheep represents a $32 \%$ decline from 1978 , and a $61 \%$ decline from the 1976 potential. The extinction rate, increased from $12 \%$ in 1978 to $20 \%$ in the reduced population. In addition to the lowered chances for survival, it would require 18 years for the reduced population to regain the previous level of 13 sheep.

Conversely, a supplemental increase in the population should decrease the extinction probability. Increasing the herd by 15 animals had a significant impact on populations extinction rate and growth potential (Fig. 1h).

The final deterministic population size of 59 sheep represents a $211 \%$ increase in potential over the 1978 population. Only six of the 50 stochastic simulations contained final population sizes below the initial 37 sheep (Fig. 1h). From a purely demographic standpoint, the introduction of 15 sheep into the existing herd could virtually eliminate the possibility of extinction, and nearly triple the present population potential over the next 18 years.

The extinction probabilities and population potentials presented in this paper are estimated. Models cannot incorporate all the ecological and behavioral variations peculiar to every species. They should not be used to predict actual population parameters at some future time. However, given the correct assumptions and reasonable data on demographic parameters $\left(b_{x}, m_{x}\right.$ and $\left.B_{x}\right)$ models can delimit a range of possibilities. In this paper we have hypothesized a reproductive pattern for desert bighorn sheep and determined a range of extinction possibilities for a remnant population. Without altering the demographic 
parameters we can validly compare outcomes among population strucfures to determine a range of constraints imposed in response to increasing, decreasing, or altering the age structure, of the base population.

One additional comment regarding such use of models should be made which relates to algebraic structure and algorithm choice within the model. The population model utilized incorporates a stochastic survival function that involves the drawing of a series of random numbers, $r$ $(0.0 \leqslant r \leqslant 1.0)$, from a uniform distribution. There is no biological basis we can discern for the use of any particular distribution of random numbers; however, the distribution that is used will affect the actual values of the extinction probabilities obtained. The use of a uniform distribution tends to accentuate the extreme causes because of the area under the tails of the distribution (relative to, say, random numbers drawn from a normal distribution). We wish to emphasize then, the comparative nature of the simulations we have presented. We do not presume to have calculated actual probabilities of extinction or survival, but we believe the comparisons between the initialized population structures, which were based on patterns existing in a remnant population, are instructive.

In these simulations, the ages of adult ewes were purposely underestimated, to provide higher reproductive potentials (Lenarz \& Conley, 1980). No age restriction on sexual maturity of rams was incorporated. Both of these factors tend to favor perpetuation of populations; therefore, the extinction probabilities generated were conservative estimates.

From these simulations several important trends emerge. The present population of desert bighorn sheep in the Big Hatchets has a definite chance of going extinct, and at best can maintain itself or double in size over the next 18 years. The decrease in the adult segment of the herd between 1976 and 1978 has significantly increased the probability of extinction and illustrates a dangerous trend in population decline. In none of the stochastic simulations of the 1976 population did the number of animals decrease as rapidly as was actually recorded in the subsequent two years. A further reduction in population would greatly increase the chance for extinction and eliminate any hope for significant increase in the next 18 years. Conversely, the addition of 15 more sheep could reverse the current trend and possibly initiate substantial population growth.

Although available data are lacking, we suggest the Big Hatchet population of $O$. c. mexicana is representative of low density Ovis populations in general, and that analysis of the kind performed here will aid our understanding of similar beleaguered populations. 


\section{REFERENCES}

1. Bear G. D. \& Jones G. W., 1973: History and distribution of bighorn sheep in Colorado. P-R Job Prog. Rep., Proj. W-41-R. Colorado Division of Wildlife, Denver.

2. Beatly J. C., 1974: Phenological events and their environmental triggers. Ecology, 55: 856-863.

3. Buechner H. K., 1960: The bighorn sheep in the United States, its past, present and future. Wildl. Monogr., 4: 1-174.

4. Clark R. T., 1934: Studies on the physiology of reproduction in sheep. I. The ovulation of the ewe as affected by the plane of nutrition. Anat. Rec., 60: $125-134$.

5. Conley W., Nichold J. D. \& Tipton A. R., 1977: Reproductive strategies in desert rodents. [In: R. H. Wauer and D. H. Riskind (Eds), "Symposium on the biological resources of the .Chihuahuan Desert: U. S. and Mexico"]. U. S. National Park Service, Trans. Proc. Ser., 3: 193-216.

6. Conley W., 1978: Demographic analysis and population modeling. [In: J. Schmidt and D. Gilbert (Eds), "Big game of North America, ecology and management"]. Stackpole Books, Inc.: 305-320. Harrisburg, PA.

7. Deming O. V., 1955: Rearing bighorn lambs in captivity. Calif. Fish and Game, 41: 131-143.

8. Fisher R. A., 1958: The genetical theory of natural selection (2nd ed.). Dover Press: 1-291. New York.

9. Geist V., 1966: Validity of horn segment counts in aging bighorn sleep. J. Wildl. Manage., 30: 634-636.

10. Geist V., 1971: Mountain sheep: a study in behaviour and evolution. Univ. of Chicago Press: 1-383. Chicago.

11. Gordon S. P., 1956: Big Hatchet bighorn studies. P-P Job Prog. Rep., Proj. W-68-R. New Mexico Game and Fish Dept., Las Cruces.

12. Hansen C. G., 1965: Growth and development of bighorn sheep. J. Vildl. Manage., 29: 387-391.

13. Hansen C. G., 1967: Bighorn sheep populations of the Desert Game Range. J. Wildl. Manage., 31: 693-706.

14. Lenarz M. S., 1979: Social structure and reproductive strategy in Desert Bighorn Sheep (Ovis canadensis mexicana). J. Mammal., 60: 671-678.

15. Lenarz M. S. \& Conley W., 1980: Demographic considerations in reintroduction programs of bighorn sheep. Acta theriol., 25: 71-81.

16. Lotka A. J., 1956: Elements of mathematical biology. Dover Press: 1-465. New York.

17. Marshall F. R., Potts C. G., 1921: Flushing and other means of incressing lamb yields. U. S. Dept. Agr., Dept. Bull., 996: 1-14.

18. McCutchen H. E., 1977: A minimum breeding age for a desert bighorn ewe. Southwestern Nat., 22: 153.

19. Miller R. E., Hart G. H. \& Cole H. H., 1942: Fertility in sheep as affected by nutrition during the breeding season and pregnancy. Calif. Agr. Exp. Sta. Bull. 672 : $1-31$.

20. Monson G., 1963: Some desert bighorn reflections. Desert Bighorn Cuncil Trans. 7: $61-63$. 
21. Monson G., 1971: Distribution and abundance. [In: L. Sumner and G. Monson (Eds), "The desert bighorn: its life history, ecology and management"]. Desert Bighorn Council. In Press.

22. Spalding D. J., 1966: Twinning in bighorn sheep. J. Wildl. Manage., 30: 207.

23. Streeter R. G., 1970: A literature review on bighorn sheep population dynamics. Special Rep. No. 24. Colorado Division of Game, Fish and Parks. 11 p.

24. Sudgen L. G., 1961: The California bighorn in British Columbia, British Columbia Dept. Rec. and Conserv., Victoria: $1-58$.

25. Thompson A. M. \& Thompson W., 1949: Lambing in relation to diet of the pregnant ewe. Brit. J. Nutr., 2: 290-305.

26. Wallace I. R., 1948: The growth of lambs before and after birth in relation to the level of nutrition. J. Agr. Sci., 38: 93-153.

27. Watts T., 1978: Desert bighorn sheep investigations. P-R Job Prog. Rep., Proj. W-122-R. New Mexico Game and Fish Dept., Las Cruces.

28 Welles R. E. \& Welles F. B., 1961: The bighorn of Death Valley. Fauna of the National Parks of the United States. No. 6: 1-242.

29. Woodgerd W., 1964: Population dynamics of bighorn sheep on Wildhorse Island. J. Wild. Manage., 28: 381-391.

Accepted, March 25, 1981.

Tom WATTS i Walt CONLEY

\section{PRAWDOPODOBIENSTWO WYGINIĘCIA SZCZĄTKOWEJ POPULACJI OVIS CANADENSIS MEXICANA}

\section{Streszczenie}

Wyniszczanie przez człowieka Ovis canadensis (Shaw, 1804) w Północnej Ameryce spowodowało powstanie licznych, drobnych, szczątkowych populacji, występujących w izolacji od pozostałych owiec. Przeżycie tych populacji zależy od biologicznego potencjału pozostałych zwierząt oraz od zabiegów ze strony człowieka. W jednym z takich stad O. c. mexicana (Merriam, 1901), zamieszkującym góry Big Hatchet w Nowym Meksyku, doświadczalnie obniżono ilość dorosłych osobników o $50 \%$ (z 22 do 13 sztuk) w okresie między 1976 a 1978 rokiem. Przy pomocy komputera symulowano następujące modele: (1) Jakie jest prawdopodobieństwo przeżycia lub wyginięcia populacji o stanie liczebnym z 1978 r.? (2) Jaki wpływ miała redukcja stanu liczebności doroslych owiec w latach 1976-1978 na to prawdopodobieństwo?

Poziom spadku liczebności w 1978 roku wynosił 12\%. Obserwowany spadek spowodował wzrost prawdopodobieństwa wyginięcia od 0 do $12 \%$ (Ryc. 1a, 1b, 1c; Tabela 3), oraz spadek potencjalnej wielkości populacji w ciągu 18 lat o $42 \%$. Hipotetyczna 50\% (Ryc. 1g) redukcja dorosłych osobników w 1978 roku wzmogła tempo ginięcia populacji do $20 \%$ i wywołała redukcję potencjału populacji o $32 \%$. Natomiast symulowany dodatek 10 samic i 5 samców, w wieku $3-5$ lat (Tabela 2), redukowal poziom wyniszezania do zera i wzrost potencjału populacji do $211 \%$. Populacja z 1978 r. miała tendencję do wyginięcia, a trend istniejący od $1976 \mathrm{r}$. wskazuje, że mogło to nastąpić szybciej niż się spodziewano. Z demograficznego punktu widzenia, wprowadzenie 15 względnie młodych owiec zainicjuje istotny vizrost populacji (Ryc. 1h). 